\title{
Alpha-Tubulin N-Acetyltransferase
}

National Cancer Institute

\section{Source}

National Cancer Institute. Alpha-Tubulin N-Acetyltransferase. NCI Thesaurus. Code C94843.

Alpha-tubulin $\mathrm{N}$-acetyltransferase (421 aa, $\sim 47 \mathrm{kDa}$ ) is encoded by the human ATAT 1 gene. This protein is involved in protein acetylation that may be associated with neuronal development. 